\title{
IDENTIFICATION OF Phaeoisariopsis griseola PATHOTYPES FROM FIVE STATES IN BRAZIL
}

\author{
ALOISIO SARTORATO \\ Embrapa Arroz e Feijão, Cx. Postal 179, CEP 75375-000, Santo Antônio de Goiás, GO, \\ e-mail: sartorat@cnpaf.embrapa.br
}

(Aceito para publicação em 08/10/2001)

SARTORATO, A. Identification of Phaeoisariopsis griseola pathotypes from five States in Brazil. Fitopatologia Brasileira 27:078-081. 2002.

ABSTRACT

\begin{abstract}
Due to the increased importance of angular leaf spot of common bean (Phaseolus vulgaris) in Brazil, monitoring the pathogenic variability of its causal agent (Phaeoisariopsis griseola) is the best strategy for a breeding program aimed at developing resistant genotypes. Fifty one isolates of $P$. griseola collected in five Brazilian States were tested on a set of 12 international differential cultivars in the greenhouse. When inoculated plants showed symptoms but no sporulation was observed, they were transferred to a moist chamber for approximately 20-24 h. After this period of time, if no sporulation was observed, the plants were considered resistant; otherwise, they were considered susceptible.
\end{abstract}

From the fifty-one tested isolates, seven different pathotypes were identified. No Andean pathotypes were identified; consequently, all isolates were classified as Middle American pathotypes. Pathotype 63-31 was the most widespread. Pathotype 63-63 overcame resistance genes present in all differential cultivars and also the resistance gene(s) present in the cultivar AND 277. This fact has important implications for breeding angular leaf spot resistance in beans, and suggests that searching for new resistance genes to angular leaf spot must be pursued.

Additional key words: common bean, angular leaf spot, physiologic races, disease resistance.

\section{RESUMO}

\section{Identificação de patótipos de Phaeoisariopsis griseola de cinco Estados do Brasil}

Devido ao aumento da importância da mancha angular do feijoeiro comum (Phaseolus vulgaris) no Brasil, o monitoramento da variabilidade patogênica do seu agente causal (Phaeoisariopsis griseola) é uma estratégia a ser seguida em um programa de melhoramento objetivando o desenvolvimento de genótipos resistentes. Cinqüenta e um isolados de $P$. griseola coletados em cinco estados brasileiros foram testados em um conjunto de 12 cultivares diferenciadoras internacional em casa de vegetação. Quando as plantas apresentaram sintomas, mas não esporulação, elas foram transferidas para câmara úmida por aproximadamente 20-24 h. Se após este período, não foi observada esporulação, as plantas foram consideradas resis- tentes, caso contrário, suscetíveis. Dos cinqüenta e um isolados testados foram identificados sete patótipos. Não foi identificado patótipo Andino; conseqüentemente, todos os isolados foram classificados como Mesoamericanos. Dentre os patótipos identificados neste estudo, o patótipo 63-31 foi o que apresentou a maior distribuição. O patótipo 63-63 "quebrou" a resistência de todos os genes presentes nas cultivares diferenciadoras e também o gene de resistência presente na cultivar AND 277. Este fato apresenta uma implicação importante nos programas de melhoramento para a mancha angular e sugere que a procura de novos genes de resistência à doença deve continuar.

\section{INTRODUCTION}

The angular leaf spot (ALS) disease of common bean (Phaseolus vulgaris L.), caused by the fungus Phaeoisariopsis griseola (Sacc.) Ferraris is found in more than sixty countries throughout the world (Guzman et al., 1993). In recent years, this disease has been one of the most important bean production constraints in Brazil. The disease is favored by intermittent dry-wet and warm-cool weather (Correa-Victoria et al., 1989). Losses can be as high as $70 \%$ under disease favorable environmental conditions (Brenes et al., 1983; Rava et al., 1985; Sartorato \& Rava, 1992).

Angular leaf spot can be more efficiently controlled through fungicide sprays and resistant cultivars. In Brazil, chemical control has been used mainly by farmers who cultivate extensive areas of common bean, an agricultural practice that plays an important role in determining the price of beans in the market. In Brazil, however, a major part of bean production comes from medium/small or subsistence farmers who do not apply fungicides to their crops due to high cost. Consequently, breeding for disease resistance is the most practical and economical approach for angular leaf spot disease management.

The development of resistant cultivars, however, has been complicated by the pathogenic variation of the fungus (Villegas, 1959; Alvarez-Ayala \& Schwartz, 1979; Buruchara, 1983; Sartorato \& Rava, 1984; Correa-Victoria, 1987; Sartorato et al., 1991; Nietsche et al., 1997). In the past, there were innumerous methodologies to determine $P$. griseola physiological specialization (Villegas, 1959; Alvarez-Ayala 
\& Schwartz, 1979, Buruchara, 1983; Sartorato \& Rava, 1984; Correa-Victoria, 1987; Sartorato et al., 1991). In an effort to standardize the methodology for P. griseola pathotype identification, the First International Angular Leaf Spot Workshop was held at CIAT in 1995, when a set of 12 differential cultivars was established. Disease evaluation is currently carried out using a disease assessment scale of 1 to 9 (Schoonhoven \& Pastor-Corrales, 1987). On this scale, resistant phenotype scores of 1-3 are assigned to plants with limited or no symptom and no fungus sporulation whereas plants that were scored 4 or greater are considered susceptible. This new method would facilitate the exchange of pathogen and genotype information among researchers around the world.

Genetic diversity in P. griseola has been investigated by using bean cultivars as differential (Sartorato \& Rava, 1984; Pastor-Corrales \& Jara, 1995), isozyme analysis (CorreaVictoria, 1987) and RAPD (Randon Amplified Polymorphic DNA) markers (Guzman et al., 1995; Pastor-Corrales \& Jara, 1995). All results have led to the establishment of two major groups of P. griseola isolates: the Andean and the Middle American (Guzman et al., 1995). According to Guzman et al. (1995) and Pastor-Corrales \& Jara (1995), these two groups appear to have coevolved with the Andean and Middle American common bean gene pools, respectively. The establishment of these two groups suggests the incorporation of resistance genes from a given gene pool into cultivars of the other gene pool. However, the strategy for developing new resistant cultivars requires an understanding of the genetic variation of the pathogen.

The objective of this study was to identify pathotypes of $P$. griseola from isolates collected in five Brazilian States for later use in breeding programs to develop new angular leaf spot resistant bean cultivars.

\section{MATERIALS AND METHODS}

Experiments were conducted in the greenhouse of the Embrapa Rice \& Beans Research Center, Santo Antonio de Goiás, GO, Brazil.

\section{Fungal isolates}

Fifty one isolates of $P$. griseola were obtained from bean leaves collected in grower fields from the States of Santa Catarina, Paraná, Goiás, Minas Gerais and Paraíba. After a single spore isolation, the cultures were stored in individual glass flasks with sterile distilled water using the Castellani method (Figueiredo, 1967) in the refrigerator $\left( \pm 4{ }^{\circ} \mathrm{C}\right)$.

\section{Differential plant genotypes}

A set of 12 differential cultivars established at CIAT Centro Internacional de Agricultura Tropical (Pastor-Corrales \& Jara, 1995), besides the line AND 277 and the susceptible cultivar Rosinha G-2 were used for inoculation with $P$. griseola isolates (Table 1). Bean seeds were sown in aluminum pots with $2.0 \mathrm{~kg}$ of soil and five seeds/pot. Ten days after sowing, plants were thinned to three/pot.

\section{Inoculation of plants}

Spores for inoculation were obtained by culturing the fungus on bean leaf-dextrose-agar medium (Silveira, 1967) in a BOD chamber at $24 \pm 2{ }^{\circ} \mathrm{C}$. After 14 days, $5-10 \mathrm{ml}$ of sterile distilled water was added to each plate and the spore suspension was filtered in a double layer of cheesecloth for the removal of the pathogen mycelium. The spore suspension

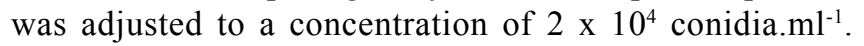
Inoculation was done when plants were in the V3 stage (Schoonhoven \& Pastor-Corrales, 1987). After inoculation, plants were incubated in a moist chamber $(>95 \% \mathrm{RH})$ for 48 $\mathrm{h}$ with a $16 \mathrm{~h}$ photoperiod.

\section{Scoring of symptoms}

Plants were maintained on greenhouse benches for another 14-18 days and evaluated for symptoms according to the 1 to 9 descriptive scale developed by Schoonhoven \& Pastor-Corrales (1987). Plant ratings of 1 to 3 were considered resistant and 4 to 9 susceptible. When inoculated plants in the greenhouse showed symptoms, with no sporulation, they were transferred to a moist chamber for 20-24 h. Plants exhibiting non-sporulating lesions were considered resistant.

\section{RESULTS AND DISCUSSION}

Isolates exhibited a different virulence pattern when inoculated on the 12 bean differential genotypes. From the 51 isolates tested (Table 1) seven different pathotypes were identified. Earlier studies have demonstrated the great pathogenic variability presented by $P$. griseola (Villegas, 1959; Alvarez-Ayala \& Schwartz, 1979; Buruchara, 1983; Sartorato \& Rava, 1984; Correa-Victoria, 1987; Sartorato et al., 1991; Nietsche, 1997).

Pathotypes induced compatible reactions with all Andean cultivars, except pathotypes 31-23 and 55-31 (Table 2). Isolates collected at the same location showed differences in their patterns of virulence. For example, isolates 584.3, 314.1 and 623.7 (Table 1), collected from the State of Santa Catarina, belonging to the pathotypes 63-15, 63-31 and 6363 (Table 2), respectively, caused compatible reactions on ten, 11 and 12 differential genotypes, respectively. The same results were observed with isolates originated from other Brazilian States (Table 2). Similar results have been found with isolates collected in other countries (Pastor-Corrales \& Jara, 1995; Busogoro et al., 1999).

No Andean pathotypes were identified in this study. Since all pathotypes were isolated from small or mediumseeded common bean cultivars and were capable of inducing compatible reactions in either Andean or Middle American cultivars they may be classified as Middle American pathotypes (Pastor-Corrales \& Jara, 1995). Our results, support the theory that the isolates of $P$. griseola tested in this study have coevolved with the Middle American group of common beans (Guzmán et al., 1995; Pastor-Corrales \& Jara, 1995).

Among all the pathotypes identified in this study, the 
TABLE 1 - List of Phaeoisariopsis griseola isolates collected in five States of Brazil

\begin{tabular}{|c|c|c|c|c|}
\hline $\begin{array}{l}\text { Isolate } \\
\end{array}$ & Cultivar & State & County & Pathotype \\
\hline 002.3 & ---- & Goiás & Santo Antônio de Goiás & $63-31$ \\
\hline 060.4 & IPA 1 & Paraíba & Lagoa Seca & $63-39$ \\
\hline 314.1 & Rio Tibagi & Santa Catarina & --- & $63-31$ \\
\hline 384.5 & Pérola & Goiás & Santo Antônio de Goiás & $63-31$ \\
\hline 410.2 & LM 932044323 & Goiás & Santo Antônio de Goiás & $63-31$ \\
\hline 491.6 & IAC Maravilha & Paraná & Pato Branco & $63-31$ \\
\hline 497.2 & IAPAR 14 & Paraná & Pato Branco & $63-31$ \\
\hline 516.3 & Macanudo & Santa Catarina & Ituporanga & $63-31$ \\
\hline 517.2 & Macanudo & Santa Catarina & Ituporanga & $63-31$ \\
\hline 522.2 & FT 90-1863 & Santa Catarina & Ituporanga & $63-63$ \\
\hline 525.4 & FT 90-1849 & Santa Catarina & Ituporanga & $63-23$ \\
\hline 527.4 & LP 91-117 & Santa Catarina & Ituporanga & $63-63$ \\
\hline 536.1 & Diamante Negro & Santa Catarina & Ituporanga & $63-31$ \\
\hline 538.6 & Xamego & Santa Catarina & Ituporanga & $63-31$ \\
\hline 539.1 & Xamego & Santa Catarina & Ituporanga & $63-63$ \\
\hline 568.4 & Carioca & Goiás & Rio Verde & $63-31$ \\
\hline 569.2 & IAPAR 34 & Goiás & Rio Verde & $63-63$ \\
\hline 579.3 & EMPASC 201 & Santa Catarina & Urussanga & $63-63$ \\
\hline 584.2 & Carioca $80 \mathrm{SH}$ & Santa Catarian & Urussanga & $63-31$ \\
\hline 584.3 & Carioca $80 \mathrm{SH}$ & Santa Catarina & Urussanga & $63-15$ \\
\hline 594.2 & Carioca & Goiás & Anápolis & $63-63$ \\
\hline 597.3 & IAPAR 44 & Santa Catarina & Chapecó & $63-31$ \\
\hline 597.4 & IAPAR 44 & Santa Catarina & Chapecó & $63-63$ \\
\hline 607.1 & ---- & Goiás & Uruaçu & $63-31$ \\
\hline 616.1 & Carioca & Santa Catarina & Palmitos & $63-31$ \\
\hline 617.3 & Carioca & Santa Catarina & Palmitos & $63-31$ \\
\hline 620.2 & Carioca & Santa Catarina & Palmitos & $63-31$ \\
\hline 622.2 & Carioca & Santa Catarina & Palmitos & $63-31$ \\
\hline 623.7 & Carioca & Santa Catarina & Palmitos & $63-63$ \\
\hline 624.3 & Carioca & Santa Catarina & Palmitos & $63-31$ \\
\hline 627.4 & Carioca & Santa Catarina & Palmitos & $63-63$ \\
\hline 628.1 & Carioca & Santa Catarina & Caibi & $63-31$ \\
\hline 629.2 & Carioca & Santa Catarina & Caibi & $63-63$ \\
\hline 632.2 & Carioca & Santa Catarina & Caibi & $63-63$ \\
\hline 635.2 & Carioca & Santa Catarina & Caibi & $63-31$ \\
\hline 643.2 & Carioca & Santa Catarina & Caibi & $63-31$ \\
\hline 648.3 & Carioca & Santa Catarina & Palmitos & $63-63$ \\
\hline 649.4 & Carioca & Santa Catarina & Palmitos & $63-63$ \\
\hline 651.2 & Carioca & Santa Catarina & Palmitos & $63-63$ \\
\hline 653.1 & Carioca & Santa Catarina & Palmitos & $63-63$ \\
\hline 654.3 & Carioca & Santa Catarina & Palmitos & $63-63$ \\
\hline 658.1 & Carioca & Santa Catarina & Palmitos & $63-63$ \\
\hline 659.0 & Safira & Minas Gerais & Lambari & $63-63$ \\
\hline 660.0 & CI 128 & Minas Gerais & Patos de Minas & $63-63$ \\
\hline 661.0 & --- & Minas Gerais & Lavras & $63-31$ \\
\hline 662.0 & ALC 29621 & Minas Gerais & Coimbra & $63-31$ \\
\hline 668.0 & Brigida & Minas Gerais & Florestal & $63-31$ \\
\hline 669.0 & -- & Minas Gerais & Lavras & $31-23$ \\
\hline 670.0 & Carioca & Minas Gerais & Lavras & $63-39$ \\
\hline 672.0 & LM 93204453 & Minas Gerais & Florestal & $55-31$ \\
\hline 673.0 & ALC 29621 & Minas Gerais & Coimbra & $63-63$ \\
\hline
\end{tabular}

most widespread was the pathotype 63-31 (Table 3). This pathotype occurred in all Brazilian States from which isolates were collected, in spite of the small number of isolates tested from the states of Paraná and Goiás. Our results show that $39.2 \%$ (20 isolates) of the isolates belong to pathotype 63-63. This pathotype overcame all resistance genes present in the differential cultivars including those in the cultivar Cornell 49-242 which is considered to be an excellent source of resistance to this disease (Correa, 1987; Sartorato et al., 1991; Sartorato \& Rava, 1993). Even though the cultivar Cornell 49-242 showed only a few sporulating lesions when inoculated with some isolates, it was considered as susceptible.

When AND 277 was included as a differential cultivar, the pathotype 63-63 could be subdivided into two different groups of isolates representing two different pathogenic
TABLE 2 - Reaction of differential cultivars inoculated with 51 isolates of Phaeoisariopsis griseola collected in five Brazilian States

\begin{tabular}{|c|c|c|c|c|c|c|c|c|c|c|c|c|c|}
\hline \multirow[t]{2}{*}{ Pathotype } & \multicolumn{6}{|c|}{ Andean beans } & \multicolumn{6}{|c|}{$\begin{array}{c}\text { Middle American } \\
\text { beans }\end{array}$} & \multirow{2}{*}{$\begin{array}{l}\text { Number } \\
\text { of Isolates }\end{array}$} \\
\hline & $\mathbf{1}^{\mathrm{a}}$ & 2 & 3 & 4 & 5 & 6 & 7 & 8 & 9 & 10 & 11 & 12 & \\
\hline $31-23$ & $+^{b}$ & + & + & + & + & $-{ }^{c}$ & + & + & + & - & + & - & 1 \\
\hline $55-31$ & + & + & + & - & + & + & + & + & + & + & + & - & 1 \\
\hline $63-15$ & + & + & + & + & + & + & + & + & + & + & - & - & 1 \\
\hline $63-23$ & + & + & + & + & + & + & + & + & + & - & + & - & 1 \\
\hline $63-31$ & + & + & + & + & + & + & + & + & + & + & + & - & 25 \\
\hline $63-39$ & + & + & + & + & + & + & + & + & + & - & - & + & 2 \\
\hline $63-63$ & + & + & + & + & + & + & + & + & + & + & + & + & 20 \\
\hline
\end{tabular}

a (1)Don Timóteo; (2) G 11796; (3) Bolón Bayo; (4) Montcalm; (5) Amendoin; (6) G 5686: (7) Pan 72; (8) G 2858; (9) Flor de Mayo; (10) Mexico 54; (11) BAT 332; (12) Cornell 49-242.

${ }^{\mathrm{b}}$ Compatible reaction $(+)$

${ }^{\mathrm{c}}$ Incompatible reaction (-)

entities, one which included a group of isolates that overcame the AND 277 resistance gene (s) and another group which did not.

Since some isolates of the pathotype 63-63 overcome all resistance genes in the differential cultivars, the resistance gene(s) present in the cultivar AND 277 indicate that this cultivar differs in at least one resistance gene, from the differential cultivars.

The fact that the identified pathotypes overcame resistance genes of all differential cultivars and that some isolates from pathotype 63-63 shows a compatible reaction with the resistant gene(s) of AND 277, reinforces that a continuous search for new resistance gene sources of angular leaf spot in Brazil must be pursued.

The use of a humid chamber for those plants that developed symptoms but did not sporulate in the greenhouse proved to be important and helped to compare the results among different tests. Sporulation is known to be a process that depends upon temperature and relative humidity. These parameters change around the world during the year. For example: in Santo Antonio de Goiás, GO, Brazil, the same isolate can be determined as two different pathotypes if it is tested in January (rainy season) or September (dry season).

TABLE 3 - Geographical distribution of pathotypes and isolates of Phaeoisariopsis griseola identified in Brazil

\begin{tabular}{|c|c|c|c|c|c|c|}
\hline \multirow{2}{*}{ Pathotype } & \multicolumn{5}{|c|}{ Isolate Origin $^{\mathrm{a}}$} & \multirow{2}{*}{$\begin{array}{l}\text { Total Num } \\
\text { of Isolates }\end{array}$} \\
\hline & SC & PR & GO & MG & PB & \\
\hline $31-23$ & & & & 1 & & 1 \\
\hline $55-31$ & & & & 1 & & 1 \\
\hline $63-15$ & 1 & & & & & 1 \\
\hline $62-23$ & 1 & & & & & 1 \\
\hline $63-31$ & 15 & 2 & 5 & 3 & & 25 \\
\hline $63-39$ & & & & 1 & 1 & 2 \\
\hline $63-63$ & 15 & & 2 & 3 & & 20 \\
\hline Total & 32 & 2 & 7 & 9 & 1 & 51 \\
\hline
\end{tabular}

a(SC) Santa Catarina; (PR) Paraná; (GO) Goiás; (MG) Minas Gerais; (PB) Paraíba. 
Relative humidity in this part of the country during the dry season can be as low as $29 \%$ with an average of $57 \%$ from June to September. With such relative humidity, it is difficult to observe sporulation under natural conditions. Consequently, to identify the resistant phenotypes, plants showing angular leaf spot symptoms but no sporulation, should be transferred to a humid chamber for approximately $20-24 \mathrm{~h}$ to provide the necessary conditions for the fungus to sporulate.

\section{LITERATURE CITED}

ALVAREZ-AYALA, G. \& SCHWARTZ, H.F. Preliminary investigations of pathogenic variability expressed by Isariopsis griseola. Annual Report Bean Improvement Cooperative 22:8688. 1979.

BRENES, B.M., CHAVES, G.M. \& ZAMBOLIM, L. Estimativas de perdas no rendimento de feijoeiro-comum (Phaseolus vulgaris L.) causadas pela mancha-angular (Isariopsis griseola Sacc.). Fitopatologia Brasileira 8:599. 1983. (Resumo)

BURUCHARA, R.A. Determination of pathogenic variation in Isariopsis griseola Sacc. and Pseudomonas syringae pv. phaseolicola (Burk., 1926) Young, Dye and Wilkie 1978. (PhD Thesis). Nairobi. University Nairobi. 1983.

BUSOGORO, J.P., JIJAKLI, M.H. \& LEPOIVRE, P. Virulence variation and RAPD polymorphism in African isolates of Phaeoisariopsis griseola (Sacc.) Ferr., the causal agent of angular leaf spot of common bean. European Journal of Plant Pathology 105:559-569. 1999.

CORREA-VICTORIA, F.J. Pathogenic variation, production of toxic metabolites, and isoenzime analysis in Phaeoisariopsis griseola (Sacc.) Ferr. (PhD, Thesis). Michigan. Michigan State University. 1987.

CORREA-VICTORIA, F.J., PASTOR-CORRALES, M.A. \& SAETTLER, A.W. Angular leaf spot. In: Schwartz, H.F. \& Pastor-Corrales, M.A. (Eds.). Bean Production Problems in the Tropics. Cali. Centro Internacional de Agricultura Tropical. 1989. pp.59-75.

FIGUEIREDO, M.B. Aplicação do método de Castellani para conservação de fungos fitopatogênicos. Revista da Sociedade Brasileira de Fitopatologia 1:79-81. 1967.

GUZMAN, P., GILBERTSON, R.L., NODARI, R., JOHNSON, W.C., TEMPLE, S.R., MANDALA, D., MKANDAWIRE, A.B.C. \& GEPTS, P. Characterization of variability in the fungus Phaeoisariopsis griseola suggests coevolution with the common bean (Phaseolus vulgaris). Phytopathology 85:600-
607. 1995.

GUZMAN, P., MANDALA, D., GEPTS, P., NODARI, R., JOHNSON, B., TEMPLE, S., MSUKU, W.A.B., MKANDAWIRE, A.B.C. \& GILBERTSON, R.L. Genetic diversity among isolates of the angular leafspot fungus (Phaeoisariopsis griseola) revealed by random amplified polymorphic DNA (RAPDs) analysis. Annual Report Bean Improvement Cooperative 36:158-159. 1993.

NIETSCHE, S. Identificação de raças de Phaeoisariopsis griseola e determinação de fontes de resistência em Phaseolus vulgaris. (Tese de Mestrado). Viçosa. Universidade Federal de Viçosa. 1997.

PASTOR-CORRALES, M.A. \& JARA, C.E. La evolución de Phaeoisariopsis griseola com el frijol común en América Latina. Fitopatologia Colombiana 19:15-24. 1995.

RAVA, C.A., SARTORATO, A. \& CARVALHO, J.R.P. Yield losses in dry bean (Phaseolus vulgaris L.) caused by angular leaf spot (Isariopsis griseola Sacc.). Annual Report Bean Improvement Cooperative 28:5-6. 1985.

SARTORATO, A. \& RAVA, C.A. Determinação da resistência parcial do feijoeiro comum a Isariopsis griseola. In: Anais, $4^{\mathrm{a}}$ Reunião Nacional de Pesquisa de Feijão, Londrina, PR. Londrina. IAPAR. 1993. Trabalho, 43.

SARTORATO, A. \& RAVA, C.A. Especialização fisiológica de Isariopsis griseola Sacc. em Phaseolus vulgaris L. In: Anais, $6^{\circ}$ Congresso Paulista de Fitopatologia, Botucatu. 1984. Summa Phytopathologica 10:58-59. 1984.

SARTORATO, A. \& RAVA, C.A. Influência da cultivar e do número de inoculações na severidade da mancha angular (Isariopsis griseola) e nas perdas na produção do feijoeiro comum (Phaseolus vulgaris). Fitopatologia Brasileira 17:247-251. 1992.

SARTORATO, A., RAVA, C.A., MENTEN, J.O.M. \& BERGAMIN FILHO, A. Resistência vertical do feijoeiro comum (Phaseolus vulgaris) a Isariopsis griseola. Fitopatologia Brasileira 16:4346. 1991.

SCHOONHOVEN, A. van \& PASTOR-CORRALES, M.A. Sistema estándar para la evaluación de germoplasma de frijol. Cali. CIAT. 1987.

SILVEIRA, G.A. Evaluación de la resistencia de frijol a la mancha angular: algunos aspectos fisiológicos de Isariopsis griseola Sacc. y patogenicidad de algunas cepas colectadas en Costa Rica. (MS Thesis). Turrialba. Instituto Interamericano de Ciencias Agrícolas da OEA. Turrialba. 1967.

VILLEGAS, J.M. Variabilidad del Isariopsis griseola Sacc. agente causal de la mancha angular del frijol (Phaseolus vulgaris L.). (BS Thesis). Caldas. Universidad de Caldas. 1959. 